\title{
Samuel Beckett Bridge, Dublin, Ireland
}

1 Jerry Cutter BSC(Hons), CEng, FICE, FCIHT, RMaPS Director, Flint \& Neill Ltd, Stone, Berkeley, UK

2 John W. Flanagan BEng(Hons), PhD, CEng, Eur Ing, MICE, FIEI Engineer's Representative, Dublin City Council, Dublin, Eire

3 Philip Brown BEng(Hons), CEng, FICE Chief Engineer, Graham Construction, Hillsborough, UK
4 Mario Rando MEng COIIM

Senior Engineer, SEED, Valencia, Spain (Former Principal Designer, Santiago Calatrava)

5 Gaute Mo MSc

Senior Engineer, GAUTE MO AS, Oslo, Norway (Former Designer's Representative, Santiago Calatrava)
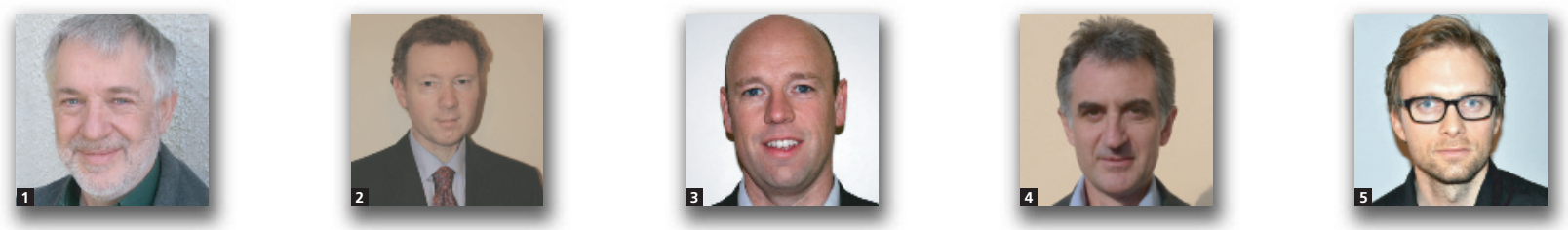

The Samuel Beckett Bridge, Dublin City's newest bridge, is now established as a landmark movable structure spanning the maritime gateway to the city. The bridge is located east of the city's centre and within the 'heart' of the newly developed docklands area, facilitating an important urban transport link for private car use, public transport, cyclists and pedestrians; and contributing towards the improved environmental, commercial and social development of the urban area in which it is located. The bridge is a Calatrava-designed, cable-stayed, steel box girder structure, with a span, across the River Liffey, of $123 \mathrm{~m}$. The bridge, which rotates through $90^{\circ}$, has an asymmetric shape reflecting that of a harp laid on its side, with the base to the cable-stayed steel pylon set outside of the river's navigational channel $28 \mathrm{~m}$ from the river's south quay wall. The pylon curves northwards to a point $\mathbf{4 6} \mathrm{m}$ above the water level with $\mathbf{2 5}$ forestay cables set in a 'harp' formation. This paper describes the basis of the bridge's structural and operational design, and the manner in which the main river support was constructed, and the superstructure fabricated and positioned.

\section{Introduction}

The Samuel Beckett Bridge, Dublin City's newest bridge, is now established as a landmark structure spanning the maritime gateway to the city. The bridge is located east of the city's centre and within the 'heart' of the newly developed docklands area, facilitating an important urban transport link for private car use, public transport, cyclists and pedestrians; and contributing towards the improved environmental, commercial and social development of the urban area in which it is located.

The design brief for the bridge sought to achieve a landmark structure of unmistakable modernity and unique character that would act as a symbol for the city and a catalyst for future development in the area. At the concept design stage a number of ideas were examined, but the one that best met the client's requirements was the concept of a bridge similar in form to the Celtic Harp, the harp being of significance as it is a symbol of Ireland (see Figure 1).
The Dublin Docklands Master Plan (Dublin Docklands Development Authority, 1997) required that all future bridges within the area have opening spans in order to facilitate the continued movement of shipping and to maintain the amenity of the river.

In 1999, Dublin City Council, the client for the project, appointed Santiago Calatrava as designer for the bridge crossing. Calatrava's brief was to provide a signature bridge design for the river crossing location together with a design for the bridge's approach roads. Calatrava appointed a local firm, Roughan and O'Donovan, to assist with the civil aspects of the bridge design, together with preparing the contract and tender documentation.

\section{Design}

\subsection{General description}

The Samuel Beckett Bridge is a cable-stayed, steel box girder structure, with a span, across the River Liffey, of $123 \mathrm{~m}$. The 
Samuel Beckett Bridge, Dublin,

Ireland

Cutter, Flanagan, Brown, Rando

and Mo

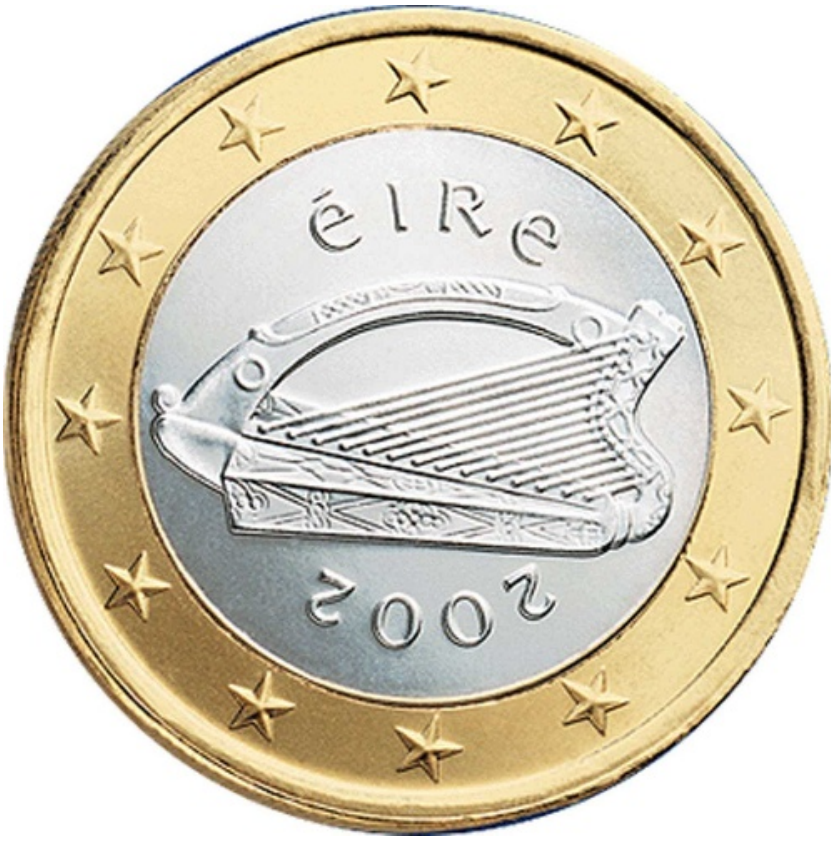

Figure 1. Irish coin with harp symbol

bridge, which rotates through $90^{\circ}$ to maintain shipping movements upstream, has an asymmetric shape, with the base to the cable-stayed steel pylon set outside of the river's central navigation channel. The pylon curves northwards to a point $46 \mathrm{~m}$ above the water level with 25 forestay cables set in a 'harp' formation. An elevation of the bridge is shown in Figure 2.
The cross-section of the deck consists of two pedestrian and cycle tracks and four lanes for vehicular traffic, two of which can be adapted to accommodate trams in the future. The cable-stays are all locked coil cables with twenty-five $60 \mathrm{~mm}$ diameter cables supporting the front span and a total of six $145 \mathrm{~mm}$ diameter cables towards the back. The main support in the river consists of bored concrete piles, with a concrete pile cap supporting a circular concrete pier of varying diameter. This houses the hydraulic turning and lifting equipment and the horizontal and vertical bearings, which support the entire bridge while turning. At each end of the bridge, locking pins are moved by hydraulic cylinders and locked into the abutments to enable the bridge to carry traffic (Table 1).

\subsection{Structural layout and design}

As the Samuel Beckett Bridge is a swing bridge, two main conditions needed to be designed for

(a) the bridge in the 'open position', with no vehicular loading and no support at the ends

(b) the bridge in the 'closed position', subject to live loadings and support at the embankments (see Figure 3).

The bridge was designed such that both of these conditions are fully satisfied, while ensuring that a fully balanced optimum weight solution was developed in order to facilitate an efficient operation. The balance of the bridge in the open position - that is, minimal net moment at the main support - is achieved by means of prescribing the mass of the counterbalance, with specified tensions for the fore and backstays, in order to achieve the required profile of the deck and to align the bridge

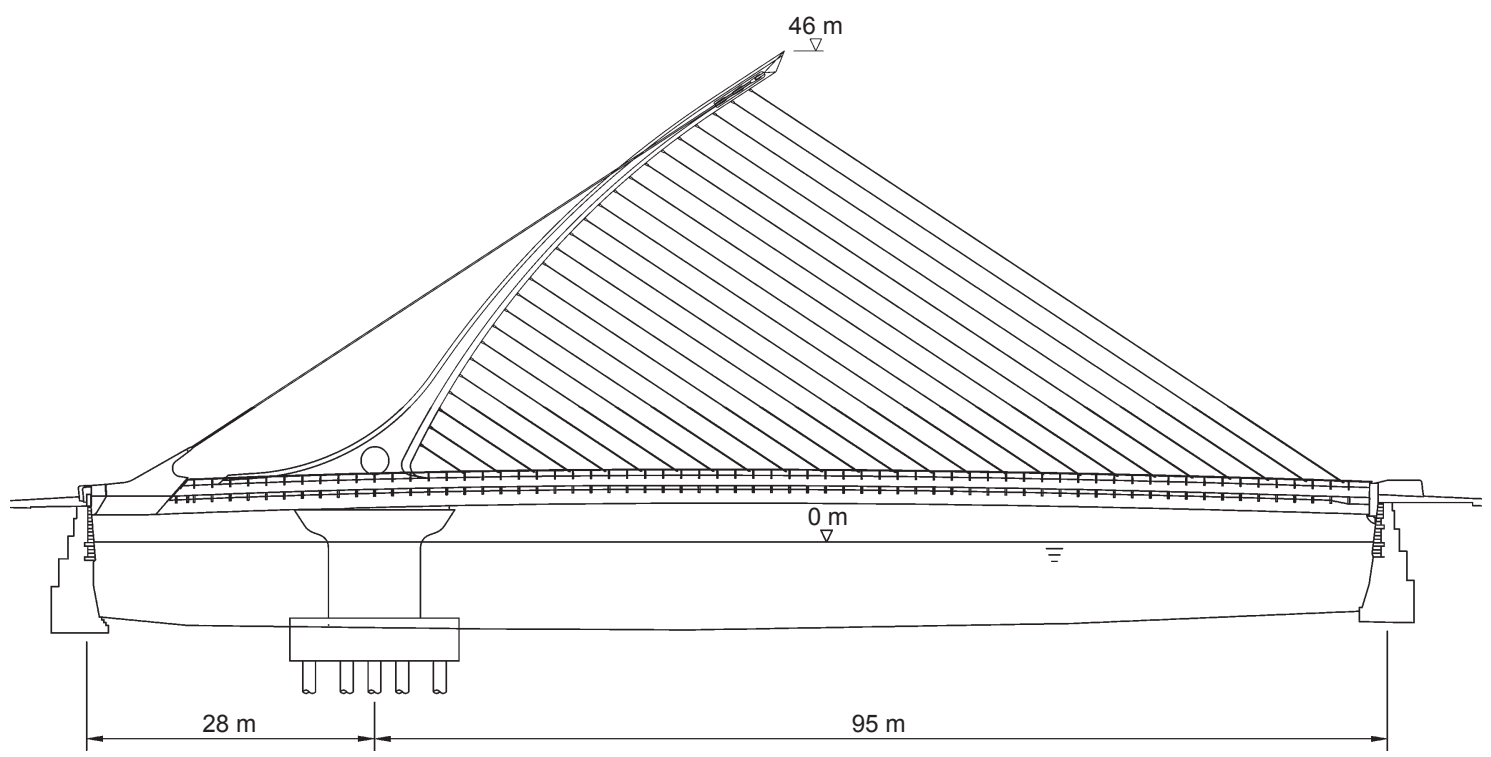

Figure 2. Elevation of the structure 
Samuel Beckett Bridge, Dublin,

Ireland

Cutter, Flanagan, Brown, Rando

and Mo
Length of bridge

Height of pylon

Width of bridge

Steel tonnage

Deck

Pylon

Cables

Steel + heavy

concrete

Counter ballast

tonnage

\section{Table 1. Basic dimensions and data}

correctly at the abutments. Using the variables of counterbalance, mass and cable tensions allowed the control of the deck level and also minimised the axial force, bending moment and deflection of the pylon and deck. Once this balance was

$$
\text { daily tide level) }
$$

$27 \mathrm{~m}$ (front span)

$1860 \mathrm{t}$

$373 t$

$90 \mathrm{t}$

$2820 \mathrm{t}$ achieved for the open condition the bridge could be analysed in the closed position with full live load.

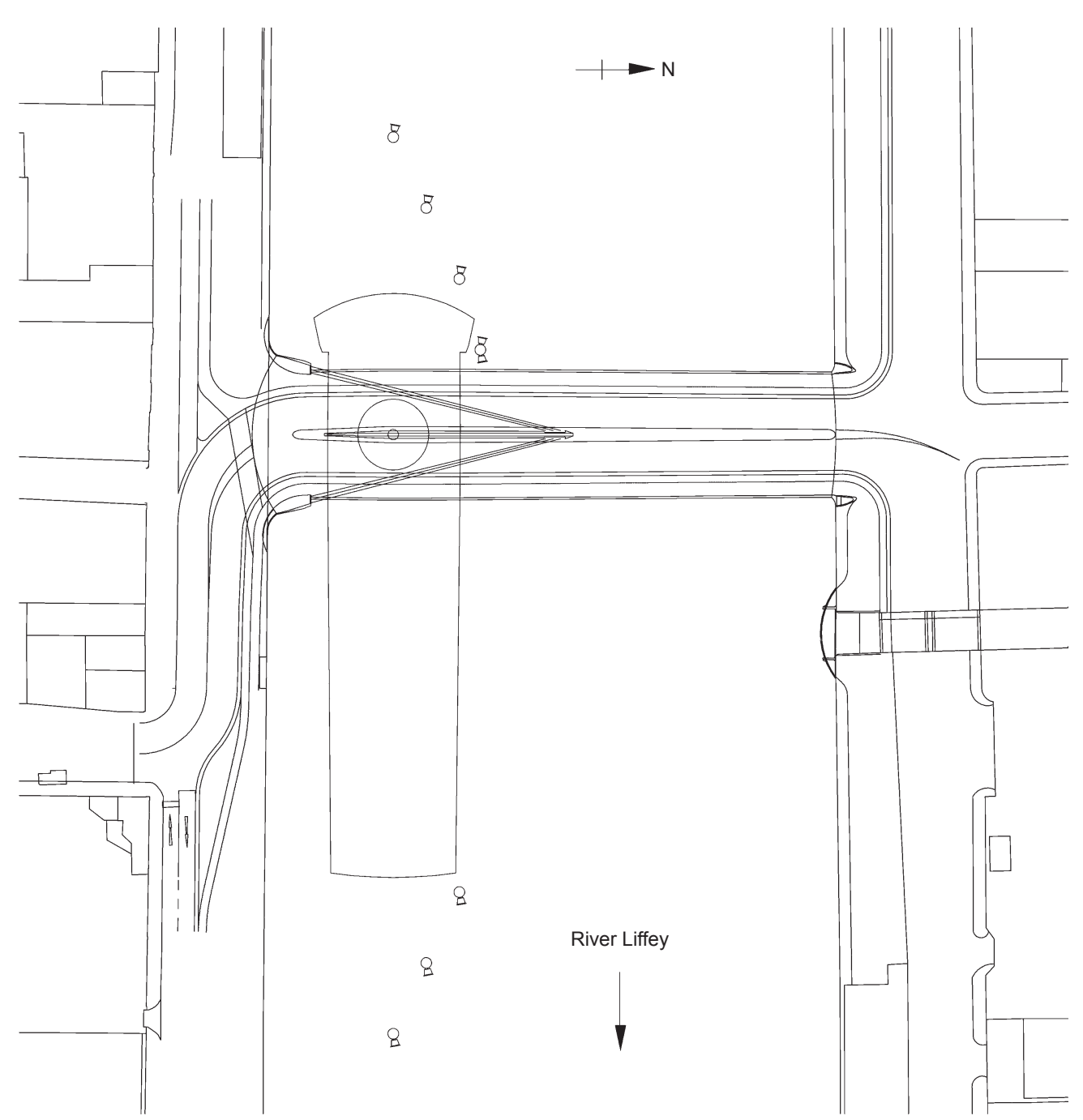

Figure 3. Plan of bridge in open and closed position 


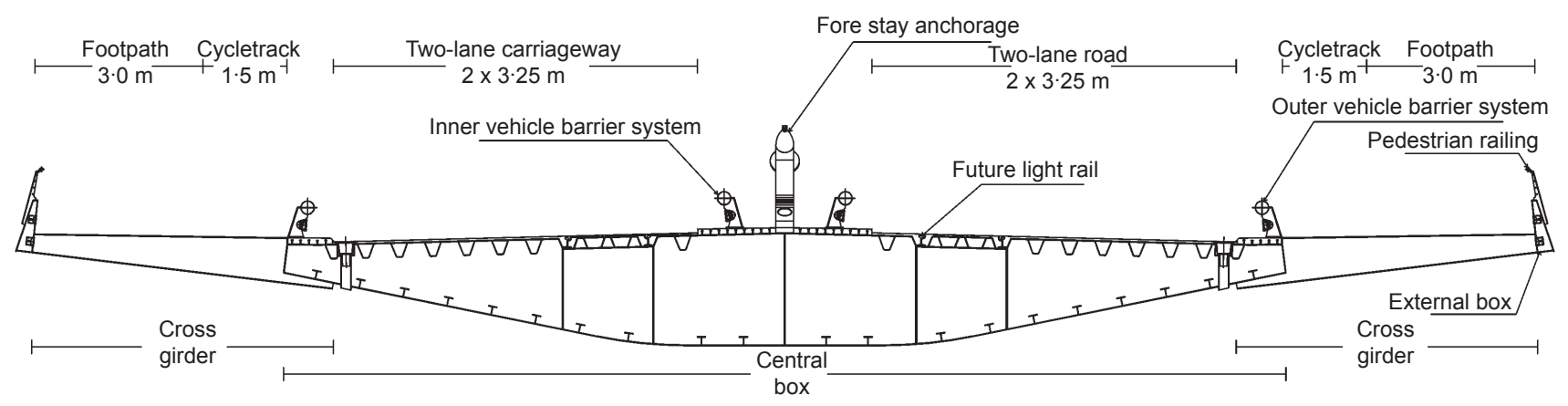

Figure 4. Section through front span

plates. The cells in the back span were generally to be filled with a combination of lead shot and concrete, which also supports the top and bottom plates, preventing them from buckling locally. The ballast material was subsequently changed by the contractor to a combination of steel blocks and heavyweight concrete (see section 4.1.3). In order to achieve the final bridge balance the amount of steel ballast placed on site during construction in these cells was adjustable. This allows for the addition or removal of mass in order to balance any future changes made to the superimposed dead loads on the bridge.

An important structural and aesthetic feature of the bridge is the single, central, line of forestays supporting the main span from a curved pylon. Such an arrangement tends to lead to large torsional forces in the deck due to unbalanced live loadings either side of the line support. Therefore, an advantage of using a multi-cell box section is its inherent torsional rigidity.

\subsubsection{Supports}

The bridge's vertical support is provided by the main support pier in the river and the locking pins at each abutment.

The main support was originally designed in steel, but at the start of the construction stage it was changed to concrete after acceptance of a proposal made by the contractor (see section 4.1.1).

The main support sits on a large pile cap in the river; it has an outer diameter of $8.6 \mathrm{~m}$ at the base and $15.0 \mathrm{~m}$ at the top, and supports the entire bridge when the bridge is turning, or when in the open position. When the bridge is either fully open or closed, the bridge sits on the outer rim of the main support, on an elastomeric bearing. When it is turning, the bridge is lifted $75 \mathrm{~mm}$ off the rim bearing by hydraulic lifting cylinders. A $10 \mathrm{~m}$ long central steel tube with a diameter of $2.5 \mathrm{~m}$, and a plate thickness of $120 \mathrm{~mm}$, welded to the superstructure below the base of the pylon, transfers the entire bridge load to the pile cap. The vertical load of $5850 \mathrm{t}$ is transferred to the lifting cylinders at the main vertical bearing at the bottom of the cylinder (on top of the pile cap), and any out-of-balance moment is taken by two horizontal bearings encircling the central steel tube $5 \cdot 35 \mathrm{~m}$ apart. The main support also houses the two hydraulic turning cylinders, which are working (due to limited space available) as a push-pull system. Figure 5 shows an illustration of the bridge's rotation mechanism within the bridge's main support pier.

The pile cap in the river, below the main support, was originally designed as a $16 \times 16 \times 4 \mathrm{~m}$ heavily reinforced pile cap. Its thickness was later reduced to $3 \mathrm{~m}$ as part of the change to a concrete support. The pile cap is supported by eighteen $1.2 \mathrm{~m}$ diameter bored cast-in-place piles, each with a capacity of $9500 \mathrm{kN}$.

At the ends of the bridge hydraulically controlled locking pins attach the bridge structure to the housings cast into the abutments. The locking pins are designed as part of the bridge rotation mechanism and provide the final alignment of the bridge, vertically and horizontally. This is necessary due to the range of deflections at the bridge ends such as temperature effects and cable sag.

The abutments are reinforced concrete structures founded on bored concrete piles as shown in Figure 6.

\subsubsection{Cable arrangement}

The front deck section spans between the main support and the north abutment. The central line of forestays effectively behaves as a row of vertical spring supports for the front span. Due to the inclination of these forestays, the stay forces have significant horizontal components along the deck, which are resisted by the deck structure acting in compression and balanced by an equal and opposite force in the back span, provided by the force at the backstays. 


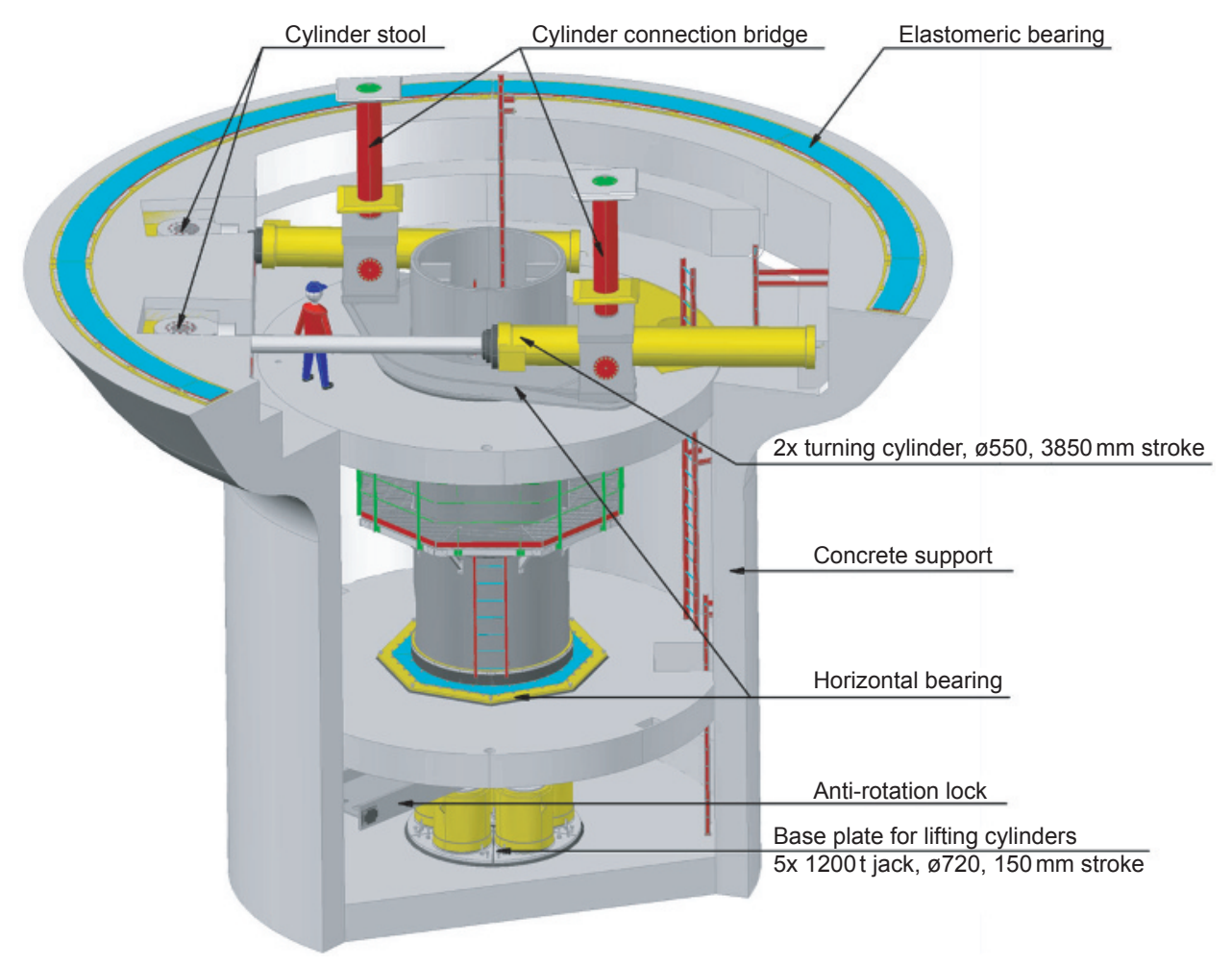

Figure 5. Illustration of the rotation system within the river pier

The backstays and forestays were supplied by Bridon and are $145 \mathrm{~mm}$ and $60 \mathrm{~mm}$ in diameter, with minimum breaking loads (MBL) of $20100 \mathrm{kN}$ and $3590 \mathrm{kN}$, respectively. An important factor for modelling the bridge behaviour and in determining the preset for fabrication of the superstructure was the cables' Young's modulus of $165 \mathrm{kN} / \mathrm{mm}^{2}$. Normally, one would accept a maximum working load in the cables of $45 \%$ (serviceability limit state) of the (minimum breaking load), but in this project,
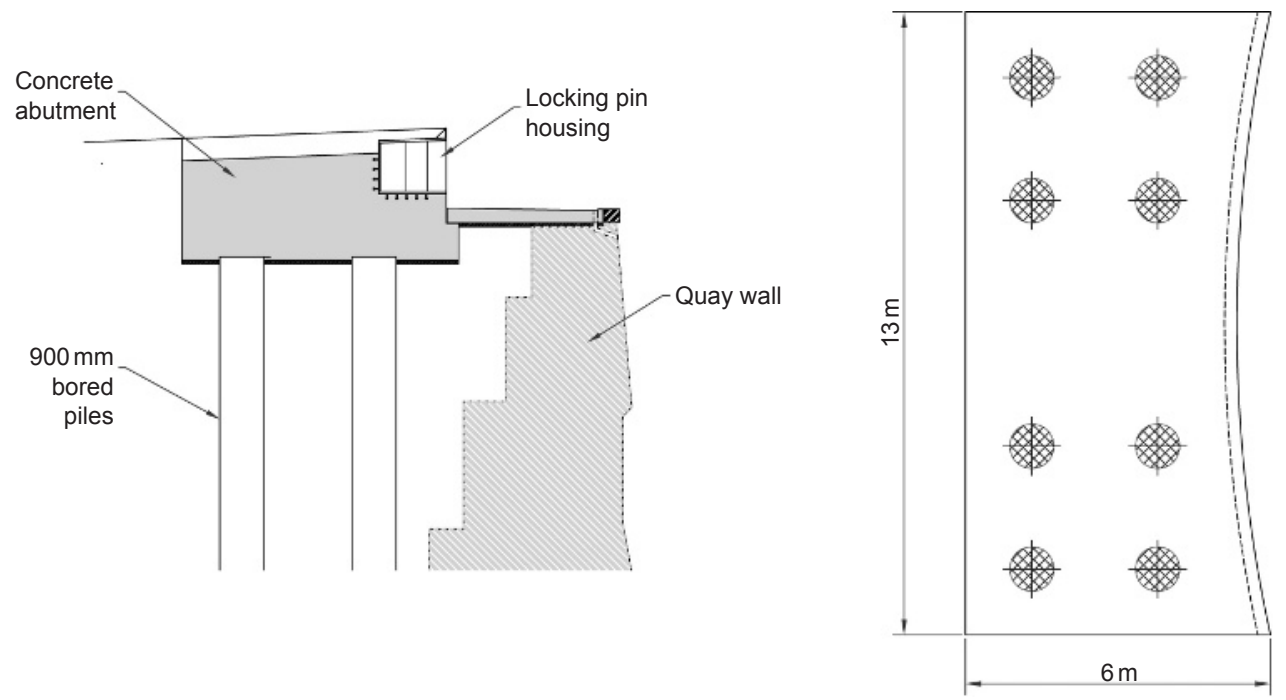

Figure 6. South abutment (plan view and section) 
because of a large proportion of permanent loads and a small proportion of varying loads, the designer and the independent checker agreed to increase this to $53 \%$ of the MBL.

\subsubsection{Pylon design}

Each of the forestays is attached to the curved, inclined and slender pylon. This was fabricated from shaped and welded thick steel plates, forming a variable box section. The pylon in turn transmits the applied cable reactions, by means of axial forces mainly, but also bending moments, to its base where it is fully connected to the main deck and the central lifting cylinder, and to its apex where it is restrained by the six inclined backstays. These backstays also provide the necessary transverse restraint of the pylon tip. The pylon, if simplified, can be considered as an arch, supported at the bottom and top, with an approximately uniform load from the forestays.

The entire superstructure was modelled using finite-element analysis, in which the pylon was checked for buckling. The pylon is restrained from buckling in the longitudinal direction due to its arched shape and by the forestays, but is slender in the transverse direction between the top and bottom where it is restrained by the backstays and deck structure.

\section{Procurement}

Following the detailed design and development of draft tender documentation, Flint \& Neill was appointed by Dublin City Council to undertake a 'procurement stage review' of the proposed scheme. This process was instigated by the client to provide them with an independent expert view of the project before the seeking of tenders. The review encompassed a wide range of headings covering procurement strategy, tender and contract documentation, selection of tenderers, elements for contractor design, constructability, tender review process and construction supervision options. The brief also required an independent estimate of the outturn cost and the optimum contract period. The review produced a range of suggestions and recommendations, which, when implemented, gave the client a much greater level of confidence to proceed with the scheme.

As part of the procurement stage review, it was established that potential tenderers would need to pre-qualify by demonstrating an ability to meet a range of criteria pertinent to this project. The steel fabrication cost element was approximately $65 \%$ of the total cost of the project and as such it was considered that the client should have a direct contractual link to the fabricator.

The successful tenderer was a joint venture between the Northern Ireland contractor, Graham, and the Dutch fabricator, Hollandia. There then followed an extended period before the formal award of contract and the establishment of the start date. This allowed all those becoming involved with the project the opportunity to absorb and understand the project requirements and to consider where savings in time, cost and other risks could be produced. Several of the resultant value engineering options are discussed in section 4.1 below.

\section{Construction}

Construction works on the 30-month contract commenced on site in May 2007. The civil and marine aspects of the project were carried out concurrently with the fabrication of the steel superstructure and the development of the bridge's rotation mechanism. The project works were supervised by the engineer's team, in which the engineer and the engineer's representative were client (Dublin City Council) in-house appointments, as were the resident engineering staff for the civils aspects of the works. Flint \& Neill were engaged within the engineer's team in providing the resident engineering staff for the steelwork. In order to deal with design-related queries and for technical approval of the contractor's proposals, a designer's representative position was created in the engineer's team, which was filled by a Calatrava engineer.

\subsection{Value engineering}

After the contract had been awarded, but before work commenced on site, the contractor proposed some alternative solutions that would provide savings to the client, improve the programme and sequencing of the work, reduce risk during construction and offer maintenance benefits over the lifetime of the bridge.

\subsubsection{Main support}

The contractor proposed to change the main pier from steel to concrete as shown in Figure 7. The client required the external appearance and profile of the pier to remain as it was and although it would be difficult to form it in concrete, the contractor felt that it was less complex than having to fabricate it in steel. In addition, the concrete pier offered the following advantages.

(a) There would be significant long-term maintenance benefits in the marine environment as no painting or cathodic protection would be required over the lifetime of the structure. It was felt that concrete offered a more sustainable solution for the marine environment.

(b) The concrete pier would be less prone to damage from floating debris or river traffic.

(c) Constructing the pier in concrete eliminated the need for sea transportation of the large steel sections and the need for a large floating crane to lift them in.

(d) It meant that the pier could be constructed at an earlier stage of the project, improving the work sequence and removing the activity from the critical path.

(e) Because of the ground conditions the contractor wanted to minimise the depth of the pile cap to ensure stability of 


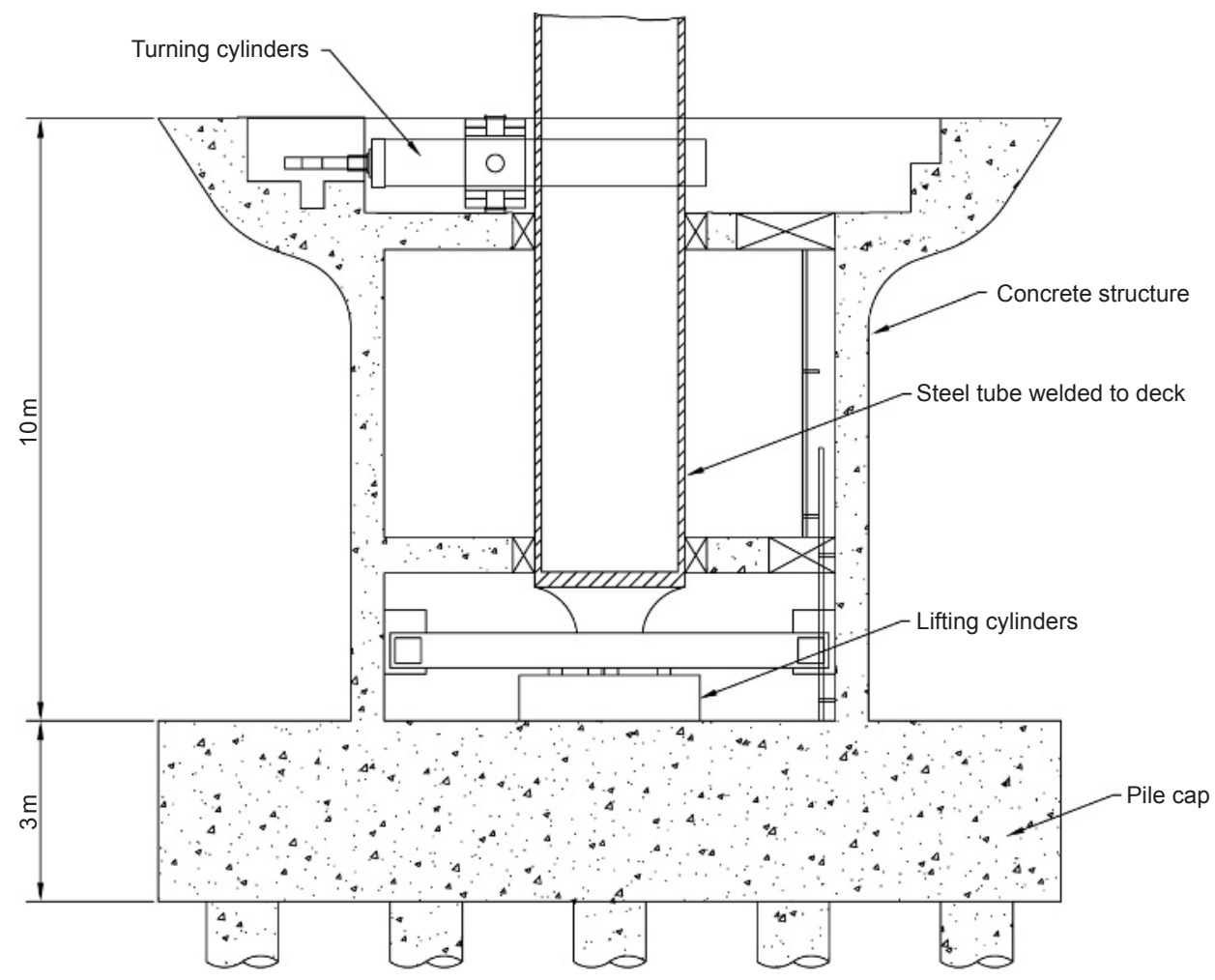

Figure 7. Main river support structure in concrete

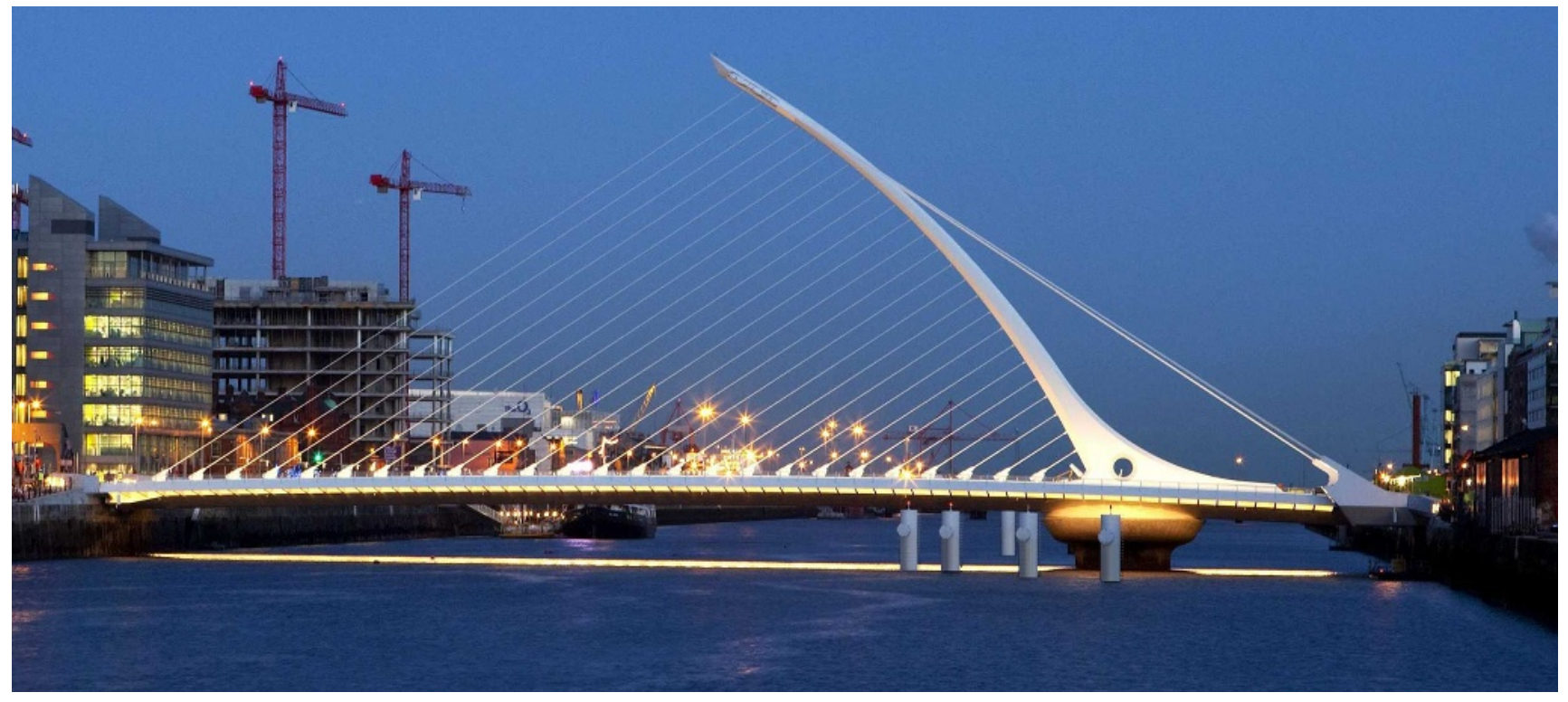

Figure 8. Samuel Beckett Bridge 
the cofferdam (see section 4.2). Changing the pier from steel to concrete enabled the contractor to redesign the pile cap and reduce its thickness from $4 \mathrm{~m}$, which was required for the steel pier, to $3 \mathrm{~m}$.

\subsubsection{Ship impact protection piles}

The entire bridge is protected against the possibility of ship impact in its open position, and the central pier is protected when it is closed. This was to be achieved using ship impact protection piles as shown in Figures 3 and 8.

The piles had originally been designed using a simple method to resist an impact from the largest vessel, which uses this part of the Port of Dublin only a few times a year. The contractor carried out a more detailed probabilistic analysis in which the annual probability of the bridge collapsing as a result of a ship impact is compared with an acceptable target probability. The vessel movement data were obtained from the Dublin Port authorities and the ship impact analysis was carried out in accordance with the AASHTO guide specification for vessel collision design of highway bridges (AASHTO, 1991). The bridge was designed for a target probability of $0 \cdot 001$, equivalent to a theoretical period between catastrophic vessel collision accidents of 1000 years. The result of this was to optimise the diameter of the piles, which meant that they could be constructed using conventional floating plant and piling rigs.

The above contractor's proposals were accepted by the client on the basis that the contractor became responsible for the alternative designs for the various elements.

\subsubsection{Ballast materials}

At the tender stage, the materials specified to provide the necessary counterweight to balance the bridge were lead shot and concrete. At that time the price of lead, quoted at the London Metals Exchange, had been rising markedly and was continuing to increase. Significant increased costs could be avoided if the balance of the bridge could be achieved using alternative materials.

The contractor developed a proposal to replace the lead and concrete ballast material with the alternative combination of steel blocks and heavyweight concrete with a density of $3 \cdot 9 \mathrm{t} / \mathrm{m}^{3}$ using magnetite aggregate.

\subsubsection{Superstructure erection}

The bridge steel superstructure, including the bridge deck and pylon, was initially planned to be assembled and erected alongside the river's quay wall, over the supporting pier, on a temporary platform in the river with individual sections lifted into place using a heavy lift marine crane. It was envisaged within the tender documentation that once the bridge superstructure was complete the falsework could be removed allowing the balanced structure to rest on the supporting pier. However, on examination of this proposed method, the contractor considered an alternative method entailing the assembly of the complete bridge superstructure within Hollandia's fabrication facility in Rotterdam and transportation by sea to Dublin. This alternative method was proposed to the engineer, who on careful examination accepted the proposal. There were clear advantages in the alternative proposal, particularly relating to the increased quality of workmanship that would be possible by fabricating the superstructure within the fabrication facility, and the resultant reduced environmental impact of the works on the confined urban site.

\subsection{Construction of main support}

One of the most significant challenges faced on site was the construction of the river pier. Following the value engineering exercise referred to in section 4.1 , the pier now consisted of a $15 \times 15 \mathrm{~m}$ hexagonal base, $3 \mathrm{~m}$ deep, with a $10 \mathrm{~m}$ high cylindrical stem widening at the top to provide support to the superstructure. It was supported on eighteen $1200 \mathrm{~mm}$ diameter bored cast-in-place concrete piles, each socketed into the rock beneath.

Immediately following award of the contract, the contractor carried out an additional site investigation around the area of the pier to supplement the investigation previously carried out at the preliminary design stage. The construction of the pier necessitated a $20 \mathrm{~m}$ square sheet piled cofferdam, and the additional site investigation provided more detailed information on the level of the rock-head, the permeability of the rock and the properties of the overburden material. It revealed that below the underside of the proposed pile cap, there would be less than $3 \mathrm{~m}$ of firm to stiff clay overlying limestone/ mudstone, which was weathered and fractured in places. This raised the possibility of water pressure in the rock exerting an uplift on the underside of the clay, such that it could cause the base of the cofferdam to heave.

Tony Gee and Partners were engaged by the contractor to carry out the design of the cofferdam. AZ46 sheet piles were driven to the top of the bedrock before the levels of walers and struts were progressively installed as the cofferdam was dewatered. Before the cofferdam could be completely dewatered, the silt had to be removed and concrete tremmied into place to act as a bottom strut. Pressure relief wells were installed to avoid the excess build-up of pressure in the rock underneath, with piezometers also installed to monitor the pressure at various locations across the base. Predetermined parameters were specified by the contractor's designer to allow work to take place safely within the cofferdam. The pressure relief wells proved to be effective and the piezometers indicated that the pressure under the base remained at safe levels during construction. 
Bridge Engineering

Volume 164 Issue BE3
Samuel Beckett Bridge, Dublin,

Ireland

Cutter, Flanagan, Brown, Rando

and Mo

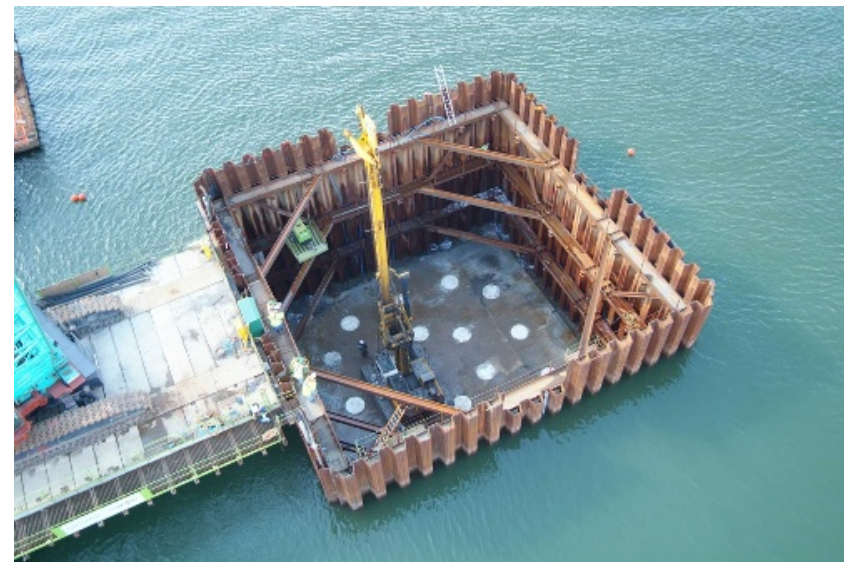

Figure 9. Pile construction within cofferdam

The installation of the foundation piles for the pier pile cap provided a particular challenge as the underside of the pile cap was approximately $13 \mathrm{~m}$ below high water level. The contractor elected to lift the piling rig into the base of the cofferdam and install the bored piles from there (see Figure 9).

This gave the piling rig greater control over the installation of the piles compared with installing them from a platform above high water level. It also meant that the piles could be installed much more quickly and safely.

The top section of the pier was complex in its geometry, with the outside surface curving in two planes. Bespoke formwork was designed and assembled and the concrete was cast in quarters - see Figure 10.

Due to the numerous interfaces with the mechanical and electrical works, considerable liaison was needed to ensure everything was cast in to the required tolerances. The largest cast-ins, each weighing approximately $2.5 \mathrm{t}$ were for connection to the main turning cylinders near the top of the pier.

All power and telemetry cables had to enter the bridge by means of the main pier as it was the point about which the bridge would rotate. Eight $120 \mathrm{~mm}$ diameter ducts were cast into the pier base and turned up the inside of the pier. Following removal of the cofferdam, they were laid in a trench in the river bed and up through the south quay wall near the bridge control room.

\subsection{Rotation system}

The rotation system was specified as a contractor-designed item with a performance specification provided by the designer. The principle for allowing the bridge to be rotated by $90^{\circ}$ consists of ensuring that the centre of gravity of the bridge (without live

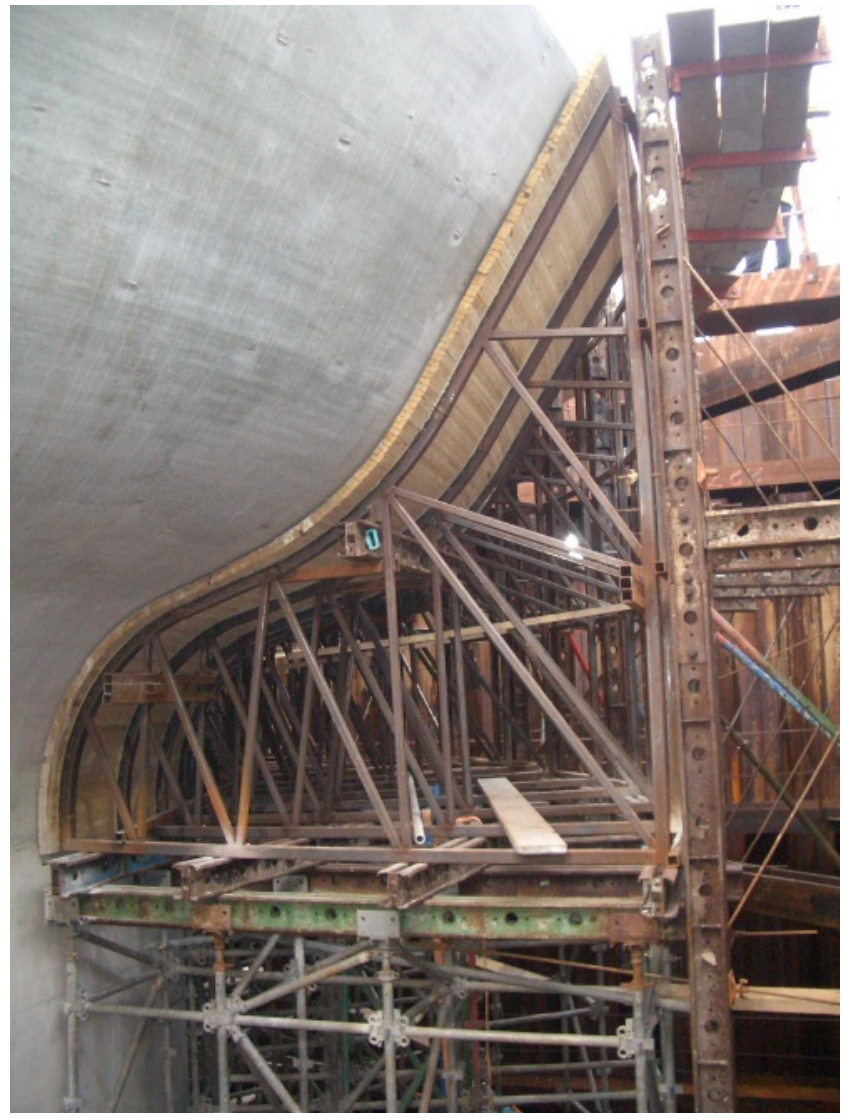

Figure 10. Bespoke formwork for quadrant of main support

load) is positioned centrally within the main support pier. A series of five hydraulic jacks lift the central steel pipe to raise the bridge, weighing $5850 \mathrm{t}, 75 \mathrm{~mm}$ off the main rim support; the pipe passes through two levels of horizontal ring bearings within the pier and is seated on a low friction bearing. Once lifted, two large hydraulic rams rotate this tube, and hence the bridge, through $90^{\circ}$. The design uses a system with one pushing and one pulling cylinder (see Figure 5).

The bridge, when in use by traffic, sits on the continuous horizontal ring bearing on the rim of the river support pier with a pair of locking pins at each end of the bridge inserted into housings cast into the abutments; these pins locate the bridge to the required position and level. An expansion joint is provided at each end of the bridge formed by movable steel boxes, which are pushed by hydraulic rams against the face of the abutments; by allowing the pressure in these hydraulic rams to vary, the bridge can expand and contract. When the bridge is required to rotate, the pressure in the rams is reversed, the boxes withdraw from the abutment faces and the locking pins are withdrawn into the bridge structure, leaving the structure free to be lifted and rotated. 
Samuel Beckett Bridge, Dublin,

Ireland

Cutter, Flanagan, Brown, Rando

and Mo

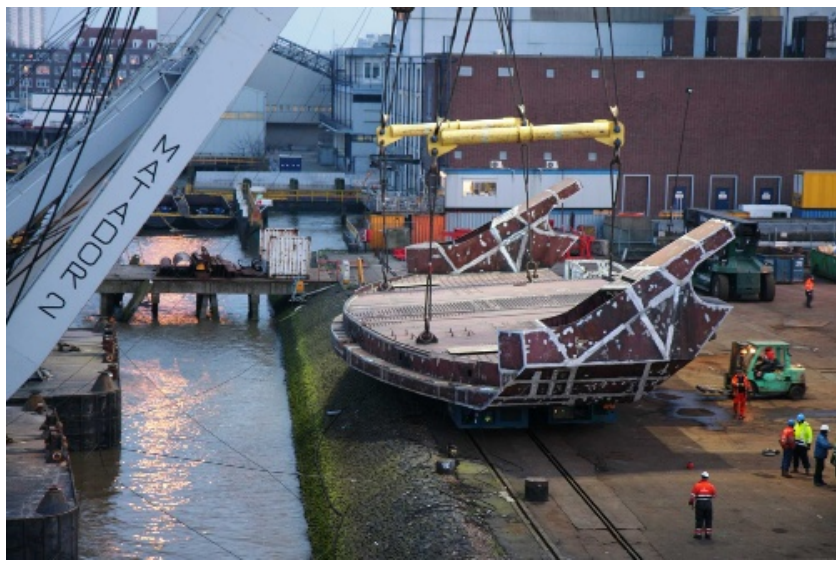

Figure 11. Backstay anchorage deck section being transported to assembly area

The electrical control cabinets, hydraulic tanks and electrical pump units are all located within the bridge deck structure close to the base of the pylon to limit the effect of their weight on the balance of the bridge.

Electrical power to the bridge is provided from the south side of the river by means of the underwater ducts into the main support pier. An emergency generator is provided within the bridge control building in case the mains supply fails.

\subsection{Fabrication and assembly}

The size of the individual elements to be fabricated was dictated by the facilities at Hollandia's workshops. The size, weight and shape of sections were dictated by the amount of handling necessary and the unit size that could be accommodated in their painting facility. The contractor determined that the bridge deck should be made up of eight sections and that these, once painted, would be joined together on a prepared assembly area where the completed unit could be easily transferred onto a seagoing barge for transport to Dublin.

The deck section weights for structural steelwork varied from $160 \mathrm{t}$ for the typical front span section up to $510 \mathrm{t}$ for the backstay anchorage deck section, excluding ballast - see Figure 11.

The pylon was fabricated in five sections; the base section was prefabricated and fitted to the bridge deck and the remaining four sections were welded together, lifted, positioned and temporarily supported while the final circumferential welds were laid.

A range of welding processes were used during fabrication, with each method selected to suit the joint configuration and position. Automated processes such as submerged arc were used whenever possible but with manual methods, mainly flux

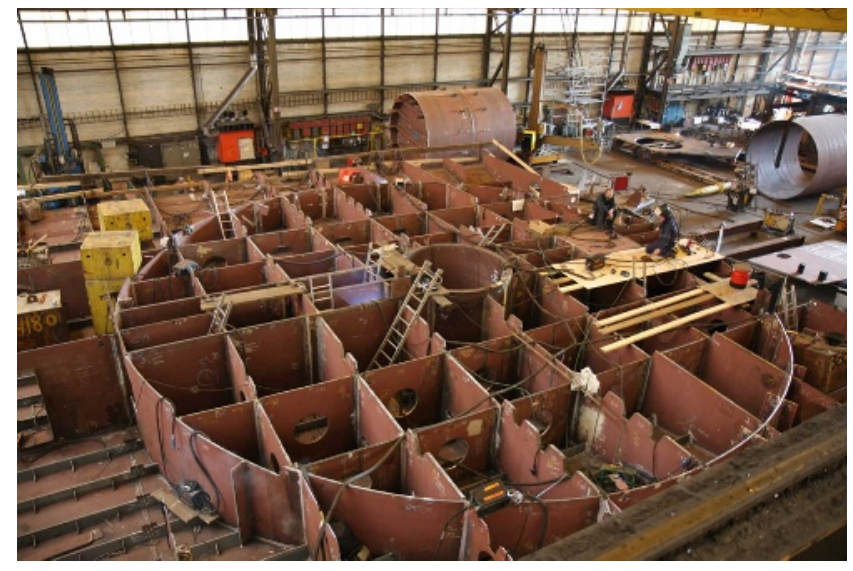

Figure 12. The 'fulcrum' bridge deck section during fabrication

core, also being used extensively. All butt welds and a proportion of fillet welds were examined using ultrasonic methods for buried defects and magnetic particle inspection for surface breaking defects.

Figure 12 shows deck section 3 during fabrication. It is this unit that sits on the rim support and is lifted by the central tube when the bridge is required to rotate.

\subsection{Superstructure transport and erection}

At the outset, the contractor investigated the maximum unit size that could be delivered to the site; the only viable method was by sea, but each unit would need to pass along the river from Hollandia's fabrication yard to the east of Rotterdam to the sea and then be able to pass through the East Link Bridge in Dublin. The East Link Bridge was found to be the limiting width restriction and the Konigshaven Bridge in Rotterdam gave the height limit. A detailed follow-up investigation identified that if some railings and street furniture could be temporarily removed from the East Link Bridge it would be possible for the complete bridge superstructure, including pylon and stays, to pass through on a suitable tide level. Detailed planning and analysis was undertaken by the contractor on the technical aspects of transferring the superstructure onto a sea barge and the fastening and ballasting requirements for the subsequent voyage (see Figure 13).

The superstructure, weighing approximately $2500 \mathrm{t}$ at this stage, was shipped to Dublin in May 2009. The journey from Rotterdam to Dublin was carefully monitored throughout the $1005 \mathrm{~km}$ journey. This took 8 days to complete as the shipment was forced to shelter from high winds for a period before traversing the Irish Sea (see Figures 14 and 15).

Following arrival in Dublin, with the bridge still supported on the barge and now moored to the quay wall, it was necessary to 
Bridge Engineering

Volume 164 Issue BE3
Samuel Beckett Bridge, Dublin,

Ireland

Cutter, Flanagan, Brown, Rando

and Mo

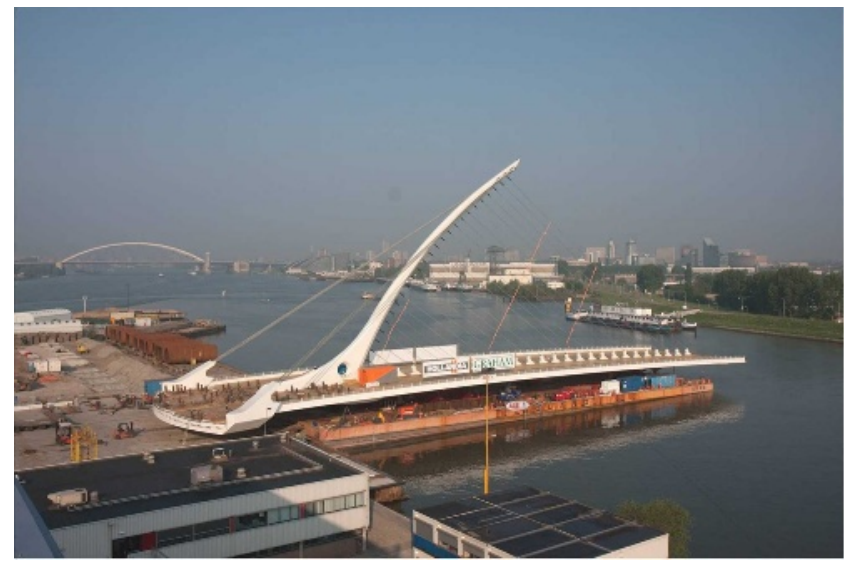

Figure 13. Bridge superstructure being transferred onto barge

ballast the back span to ensure the centre of gravity was located centrally within the support zone. The structure was then skidded along the seagoing barge to a position that allowed the backstay end to be supported on a second barge, thus leaving the bridge support area free above the river. The bridge lifting cylinder had been positioned within the main support pier and would later be welded to the main structure.

With the bridge now balanced and supported on two barges, their moorings were released and at high tide the barges were moved so as to position the bridge support area directly above the pier that had been cast in the river. Temporary guides had been welded to the bridge lifting cylinder to ensure that as the tide receded, the bridge would be lowered onto the rim support at the precise required position (see Figure 16). Once this had been achieved, and as the tide level continued to reduce, the barges could be moved away from the bridge, leaving the structure balanced and supported on the rim bearing. Once in

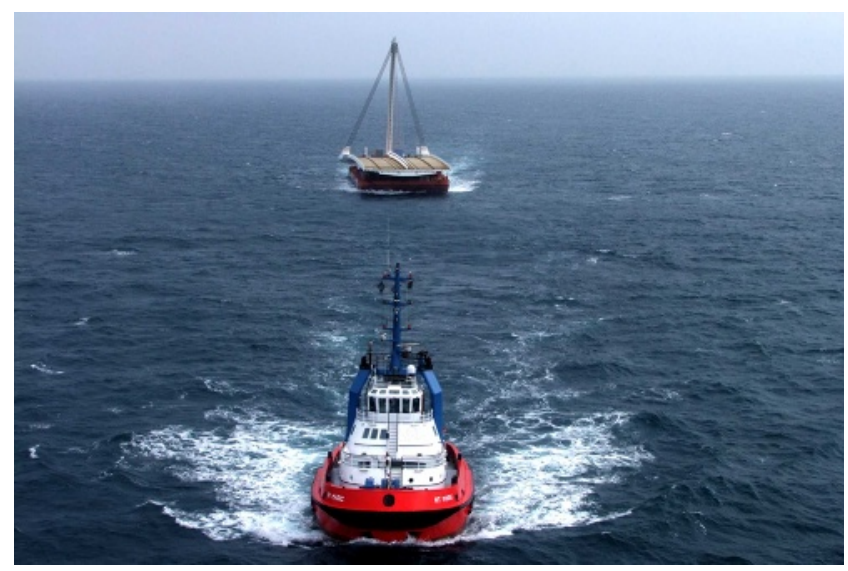

Figure 14. Bridge on barge, being towed across the Irish Sea

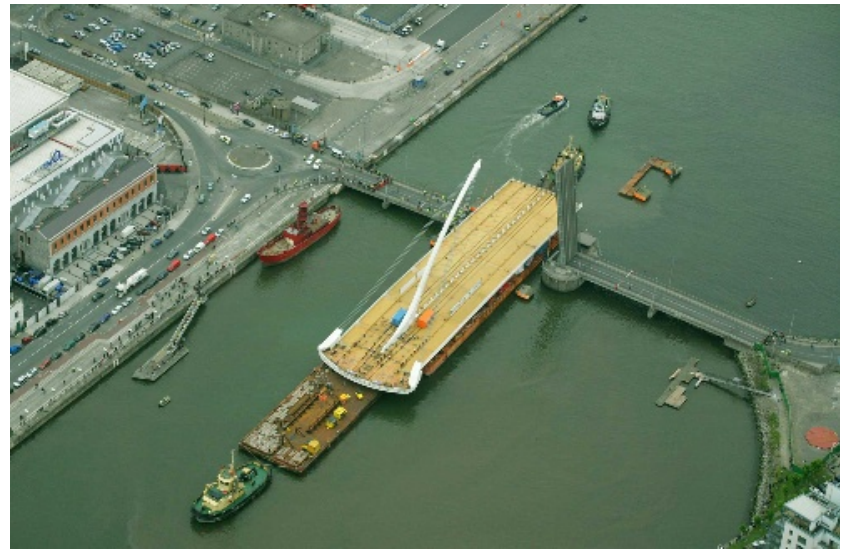

Figure 15. Bridge passing through East Link Bridge, Dublin

position, the final welded connection of the bridge lifting cylinder was made and the hydraulic system connected and temporarily activated to rotate the bridge to span the river for the first time.

\subsection{Geometry control}

Following the initial rotation of the bridge the cables were tensioned to a predetermined level and the bridge supported on temporary jacks at the locking pin locations. This allowed the reactions at the end supports to be monitored and the information fed back to the design model to allow revised stay forces to be calculated.

While fabricating and assembling the bridge in Rotterdam, the contractor had started the site works on the abutments. However, these abutments could not be completed until the bridge was positioned, as it was necessary to ensure that the bridge behaved as predicted and would fit perfectly between
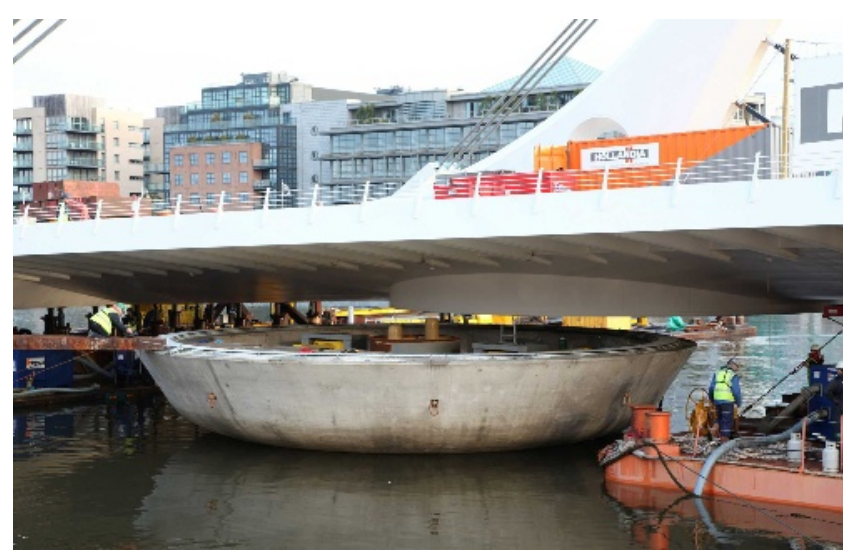

Figure 16. Bridge, supported on two barges, being placed onto main support pier 
the abutments. Once the bridge was in place, any moderate discrepancy in bridge deflection due to permanent loads was compensated for by a change to the levels at the abutments. Strict control of densities and volumes was specified, but some tolerance had to be allowed for. Some adjustment was allowed for in the cable forces, but as already described, the backstays had already been taken to the maximum acceptable level and any change that caused an increase of backstay forces could not be allowed.

During the construction of the bridge the designer's finiteelement model was continuously updated to take account of the densities, volumes and weights reported by the contractor. A significant amount of reanalysis was required at this stage to achieve a good balance between final cable forces and bridge deformations. When cable forces were changed to amend the deformation of the ends of the deck, stresses in the bridge structure changed accordingly and had to be checked. The back span of the bridge is extremely stiff, while the pylon and front span deform relatively easily. This resulted in a complex equation with numerous variables, which was finally solved by amending levels at the abutments, ballast quantities and cable forces.

\subsection{Completion}

Once the bridge was in its closed position, the top surface of the deck was shot-blasted and waterproofed before the concrete kerbs and medians were constructed using lightweight concrete in the fore span and heavyweight concrete in the back span. The carriageways were surfaced with $36 \mathrm{~mm}$ thick mastic asphalt.

The finishing works were then completed on the adjacent quays including roadworks, a granite-clad control room building and reinstatement of the masonry quay walls. The project was completed on programme in a period of 30 months. Samuel Beckett Bridge was opened by the Lord Mayor of Dublin on 10 December 2009. A photograph of the completed bridge is shown in Figure 8 .

\section{Conclusion}

The delivery of this iconic bridge was a major challenge to all the parties involved and was achieved not only through close cooperation and respect between client, designer, technical advisors and the contractor, but also by the ability and commitment of the craftsmen and operatives tasked with its production.

Due to the complexity of the bridge, the engagement of an independent project reviewer before tendering the project proved to be valuable, as was the period of time available to the contractor for value engineering in advance of work commencing on site.
The completed bridge is already recognised as a structure of unmistakable modernity acting as a symbol for the City of Dublin, and has attracted much positive publicity from residents and from visitors to the Irish capital.

\section{Acknowledgements}

The authors gratefully acknowledge the support of the client for the Samuel Beckett Bridge, Dublin City Council.

Photography was by Digital Post Productions and Peter Barrow Photographers.

In addition, the contribution of consultants, the main contractor, specialist subcontractors and operatives is acknowledged as being key to the successful completion of the project. The authors would like to thank the following project team: Client and engineer: Dublin City Council; Engineer's supervision: Dublin City Council with Flint \& Neill; Designer: Santiago Calatrava; Independent design checker: Roughan and O'Donovan; Procurement stage review: Flint \& Neill; Construction contract advisor: Roughan and O'Donovan; Construction joint venture: Graham Hollandia JV; Civil work and project management: Graham; Temporary works design: Tony Gee and Partners; Designer of alternative proposals: Aecom; Steel fabrication and M\&E development: Hollandia; Electrical and control systems: Huismann; Hydraulic systems: Hycom; Bridge sea transportation: ALE Heavylift; Bridge stay cables: Bridon UK.

\section{REFERENCES}

AASHTO (American Association of State Highway and Transportation Officials) (1991) Guide Specification and Commentary for Vessel Collision Design of Highway Bridges. Final report. AASHTO, Washington, DC. Dublin Docklands Development Authority (1997) Dublin Docklands Master Plan (1997). DDDA, Dublin, Ireland.

\section{WHAT DO YOU THINK?}

To discuss this paper, please email up to 500 words to the editor at journals@ice.org.uk. Your contribution will be forwarded to the author(s) for a reply and, if considered appropriate by the editorial panel, will be published as discussion in a future issue of the journal.

Proceedings journals rely entirely on contributions sent in by civil engineering professionals, academics and students. Papers should be 2000-5000 words long (briefing papers should be 1000-2000 words long), with adequate illustrations and references. You can submit your paper online via www.icevirtuallibrary.com/content/journals, where you will also find detailed author guidelines. 